\title{
ACOTACIONES A EDUCACIÓN POR EL ARTE, DE HERBERT READ
}

\section{NOTES TO EDUCATION BY ART, BY HERBERT READ}

\author{
José Luis Crespo-Fajardo \\ Universidad de Cuenca (Ecuador) \\ luis.crespo@ucuenca.edu.ec \\ Luisa Pillacela-Chin \\ Investigadora Independiente (Ecuador) \\ luisap_42@hotmail.com
}

Recibido: 25 febrero 2020 Aceptado: 07 marzo 2020

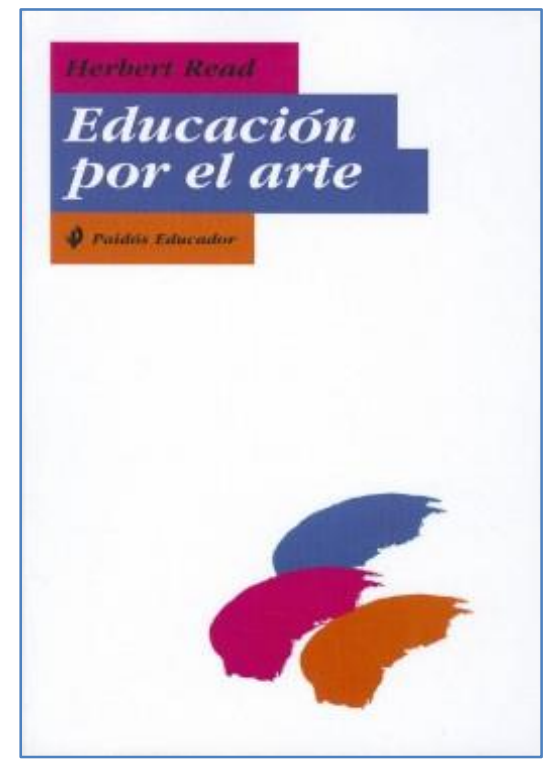

Hoy comentamos uno de los textos más influyentes del siglo XX en la pedagogía estética: Educación por el arte, originalmente publicado en 1943, contribución cardinal del poeta y polígrafo inglés Herbert Read.

$\mathrm{Su}$ propósito inicial es retomar la fundamentación platónica de que el arte debería ser la base de la educación, idea completamente olvidada en la enseñanza moderna, cimentada en la lógica, la ciencia y la gramática. Sin embargo, Read demostrará que educar la sensibilidad estética es esencial para que las personas lleguen a ser quienes son y lleguen a ser quienes no son. Es decir, desarrollar las potencialidades del individuo para que sea de valor para la humanidad.

La educación es un proceso de integración, y a veces se ha establecido autoritariamente. En cambio, Platón postulaba la libertad para que la educación tomara forma de juego, ya que así podrían apreciarse mejor las aptitudes naturales de cada estudiante. Para Read la educación es cultivar diferentes modos de expresión: enseñar a 
hacer sonidos, imágenes, movimientos y herramientas. Por tanto, educar tiene como objetivo crear artistas: personas eficientes en estos diversos modos de expresión.

Así, en los primeros capítulos se ocupa de definir términos. Concretar qué es arte o qué es educación es realmente complejo. El arte es uno de los conceptos más escurridizos de la historia, y ha sido considerado ora un fenómeno metafísico, ora algo cuantificable y medible. Lo que es claro es que está presente en todo lo que implica nuestros sentidos. La belleza, por ejemplo, encierra una armonía de proporciones matemáticas que nos suscita una emoción.

Herbert Read distingue cuatro tipos de estética expresados en las artes visuales: naturalismo, idealismo, expresionismo y abstraccionismo. Sin embargo, admite que pueden existir tantos tipos de arte como tipos de hombres, y que las formas de arte son tan diversas como las formas de la vida. Posteriormente se adentra en la psicología de la percepción visual, los factores estéticos del percepto (el contenido mental de la percepción) que inducen a una discriminación, y las diferencias entre percibir e imaginar. Aquí sale a colación la cuestión de las imágenes eidéticas, excepcionalmente vívidas en los niños de corta edad y en los artistas. Esta facultad de visualizar una imagen mental nítidamente ante los ojos, casi como si se tratase de una alucinación, se cree que la poseían los pintores Hogarth y William Blake. Se trata de una cualidad, no obstante, tiende a ser reprimida, debido a la preferencia de la educación académica hacia los saberes lógicos, científicos y gramáticos, prácticamente ninguneando al arte.

Resulta especialmente interesante el análisis del autor sobre el aprendizaje del arte en el niño a partir de la motricidad y el desarrollo de la experiencia sensorial, con el intermedio de la voluntad y de su capacidad de crear desde los ideales que se ha formado del mundo. Durante la preparación de este libro, Herbert Read visitó numerosas escuelas como observador con el fin de ver el trabajo en las clases de arte. Los niños son su foco de atención porque, como los salvajes, como los animales, experimentan la vida de forma directa, no desde una distancia mental. Para ellos el arte es un elemento de integración natural de la percepción y el sentimiento. La educación no contempla ese papel en su doctrina, y la verdad es que, de ocuparlo, llevaría aparejada toda una reforma de la sociedad actual, que es profundamente intelectualista. 
La gente no sabe reconocer la naturaleza del arte, no lo aprecia y ni siquiera intuye la conexión entre arte, bondad y nobleza de alma que ya señaló Platón en el siglo IV a. C. El filósofo griego adujo que la disposición moral del alma va unida al sentimiento estético, presente en el ritmo y la armonía, conceptos que abarcan todas las actividades humanas, de manera que cualquier persona es una suerte especial de artista. Ahora vivimos en un mundo de gramáticos y las artes se consideran recreaciones para refrescar el entendimiento. ¿Quién está abogando por la educación por el arte?, se pregunta Read. El panorama actual hace que su interrogación resuene con un eco estridente, en tanto se evidencia que las líneas de investigación académicas vigentes en educación artística se obcecan en el marasmo de las nuevas tecnologías y la sociedad del conocimiento, haciendo caso omiso a lo esencial: el arte es aquello que nos hace humanos. Las acciones, congresos y mesas redondas de asociaciones como InSEA (International Society for Education Through Art) y CLEA (Consejo Latinoamericano de Educación por el Arte), apenas son empresas aisladas en el piélago de conceptos anclados en viejas mentalidades que aún resta por transformar.

Read, Herbert (1995) Educación por el arte. Paidós educador: Barcelona. Traducción de Luis Fabricant. 